Editorial

\title{
Role of Oxidative, Nitrative, and Chlorinative Protein Modifications in Aging and Age-Related Diseases
}

\author{
Izabela Sadowska-Bartosz $\mathbb{D},{ }^{1}$ Grzegorz Bartosz $\mathbb{D},{ }^{2}$ Tilman Grune, ${ }^{3}$ \\ and Jolanta Sereikaite ${ }^{4}{ }^{4}$ \\ ${ }^{1}$ Department of Analytical Biochemistry, Faculty of Biology and Agriculture, University of Rzeszow, Zelwerowicza Street 4, \\ 35-601 Rzeszow, Poland \\ ${ }^{2}$ Department of Molecular Biology, Faculty of Biology and Environmental Protection, University of Łódź, Pomorska 141/143, \\ 90-236 Łódź, Poland \\ ${ }^{3}$ Department of Molecular Toxicology, German Institute of Human Nutrition Potsdam-Rehbruecke (DIfE), Arthur-Scheunert- \\ Allee 114-116, 14558 Nuthetal, Germany \\ ${ }^{4}$ Department of Chemistry and Bioengineering, Faculty of Fundamental Sciences, Vilnius Gediminas Technical University, \\ Sauletekio al. 11, LT-2040 Vilnius, Lithuania
}

Correspondence should be addressed to Izabela Sadowska-Bartosz; isadowska@poczta.fm

Received 15 April 2018; Accepted 17 April 2018; Published 7 August 2018

Copyright (c) 2018 Izabela Sadowska-Bartosz et al. This is an open access article distributed under the Creative Commons Attribution License, which permits unrestricted use, distribution, and reproduction in any medium, provided the original work is properly cited.

Despite extensive studies, the molecular basis of physiological aging is still poorly understood. Reactive oxygen species (ROS) and reactive nitrogen species (RNS) as well as reactive halogen species (RXS) species are believed to play a key role in the aging process. They are generated during aerobic metabolism in living organisms. The term "reactive oxygen species" includes both free radicals (molecules having an odd electron, like superoxide radical anion $\left(\mathrm{O}_{2}{ }^{--}\right)$and hydroxyl radical $\left(\mathrm{HO}^{\bullet}\right)$ ) and species that are not free radicals, like hydrogen peroxide $\left(\mathrm{H}_{2} \mathrm{O}_{2}\right)$, singlet oxygen $\left({ }^{1} \mathrm{O}_{2}\right)$, and ozone $\left(\mathrm{O}_{3}\right)$. The primary source of RNS is usually the nitric oxide radical ( $\left.{ }^{\circ} \mathrm{NO}\right)$. In consequence of ROS and RNS reactions, peroxynitrite $\mathrm{ONOO}^{-}$, anion of peroxynitrous acid $\mathrm{ONOOH}$, may be formed via the near diffusion-limited reaction of ${ }^{\bullet} \mathrm{NO}$ and $\mathrm{O}_{2}{ }^{\bullet-}$. The term "reactive nitrogen species" includes also nitrous acid $\left(\mathrm{HNO}_{2}\right)$, dinitrogen trioxide $\left(\mathrm{N}_{2} \mathrm{O}_{3}\right)$, nitrosyl anion $\left(\mathrm{NO}^{-}\right)$, nitrosyl cation $\left(\mathrm{NO}^{+}\right)$, nitrogen dioxide radical $\left({ }^{\bullet} \mathrm{NO}_{2}\right)$, peroxynitrate $\left(\mathrm{ONOOO}^{-}\right)$, peroxynitric acid $(\mathrm{ONOOOH})$, nitryl chloride $\left(\mathrm{NO}_{2} \mathrm{Cl}\right)$, and nitronium cation $\left(\mathrm{NO}_{2}^{+}\right)[1,2]$. Reactive halogen species include $\mathrm{HOCl}, \mathrm{HOBr}, \mathrm{HOI}$, chlorine, bromine, iodine, and so on. Hypohalogenous acids ( $\mathrm{HOX} ; \mathrm{X}=\mathrm{F}, \mathrm{Cl}, \mathrm{Br}$, or I) are formed in the body mainly by oxidation of halogen ions by myeloperoxidase. The imbalance between ROS, RNS, and RXS production and the antioxidant defense, in favor of prooxidants, is called oxidative, nitr(os)ative, and halogenative stress (OS, NS, and XS), respectively. Although at physiological concentrations ROS, RNS, and RXS can function as signaling molecules regulating cell proliferation, growth, differentiation, and apoptosis $[3,4]$, they react with and damage all classes of endogenous macromolecules including proteins, nucleic acids, lipids, and carbohydrates [5]. Proteins are the main targets for such modifications as they are the most abundant cell components in the terms of mass content. The level of protein damage increases under stress conditions and can be in principle an integrative measure of the exposure to OS, NS, and XS. Another source of protein modification is glycoxidation leading to the formation of advanced glycation end products (AGEs).

In this issue, the comprehensive review by A. L. Santos and A. B. Lindner presents the interplay of nonenzymatic posttranslational protein modifications in aging-associated molecular processes underlying eukaryotic aging. Understanding of the roles played by posttranslational protein 
modifications in aging and age-related diseases can facilitate targeted therapies or interventions in these diseases and the aging process itself. The review highlights also the potential of simple prokaryotic models to uncover complex agingassociated molecular processes in the emerging field of microbiogerontology. D. Weber et al. summarize the results of the European multicenter study MARK-AGE from 1559 participants. They demonstrate that, among others, protein carbonyls and 3-nitrotyrosine are biomarkers with the highest correlation with age.

Protein carbonyls are the most frequently assayed protein modification by ROS, RNS, and RXS. In this issue, M. Adamczyk-Sowa et al. demonstrate that blood serum proteins of multiple sclerosis patients suffer oxidative modifications, which are attenuated by interferon beta and further by coadministration of interferon beta and the antioxidant melatonin.

The pyrin domain-containing 3 (NLRP3) inflammasome, as a vital component of the innate immune system, is implicated in the pathogenesis of type 2 diabetes. X. Kong et al. show that the administration of AGEs $(120 \mathrm{mg} / \mathrm{kg}$ for 6 weeks) in C57BL/6J mice induced an abnormal response to glucose, pancreatic $\beta$-cell ultrastructural lesion, and cell death. Ablation of the NLRP3 inflammasome or treatment with antioxidant $\mathrm{N}$-acetyl-cysteine (NAC) clearly ameliorated these effects, suggesting AGE-induced NLRP3 inflammasome activation as a mechanism for pancreatic islet damage. J. Bai et al. provide evidence that ghrelin, a growth hormone-releasing peptide, protects against $\mathrm{H}_{2} \mathrm{O}_{2}$-induced oxidative stress in human lens epithelial cells and rat lenses. Their results suggest that ghrelin may prevent the progression of cataracts, a result that is potentially valuable for the clinical treatment of cataracts.

The articles contained in this special issue extend our knowledge on the role of nonenzymatic posttranslational protein modifications in age-related diseases and aging.

\section{Izabela Sadowska-Bartosz Grzegorz Bartosz Tilman Grune Jolanta Sereikaite}

[4] E. Barbieri and P. Sestili, "Reactive oxygen species in skeletal muscle signaling," Journal of Signal Transduction, vol. 2012, Article ID 982794, 17 pages, 2012.

[5] G. Aldini, G. Vistoli, M. Stefek et al., "Molecular strategies to prevent, inhibit, and degrade advanced glycoxidation and advanced lipoxidation end products," Free Radical Research, vol. 47, Supplement 1, pp. 93-137, 2013.

\section{References}

[1] R. B. Mikkelsen and P. Wardman, "Biological chemistry of reactive oxygen and nitrogen and radiation-induced signal transduction mechanisms," Oncogene, vol. 22, no. 37, pp. 57345754, 2003.

[2] I. Sadowska-Bartosz, C. Ott, T. Grune, and G. Bartosz, "Posttranslational protein modifications by reactive nitrogen and chlorine species and strategies for their prevention and elimination," Free Radical Research, vol. 48, no. 11, pp. 1267-1284, 2014.

[3] G. Bartosz, "Reactive oxygen species: destroyers or messengers?," Biochemical Pharmacology, vol. 77, no. 8, pp. 1303$1315,2009$. 


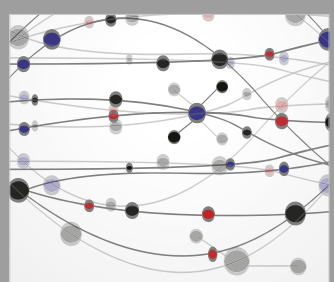

The Scientific World Journal
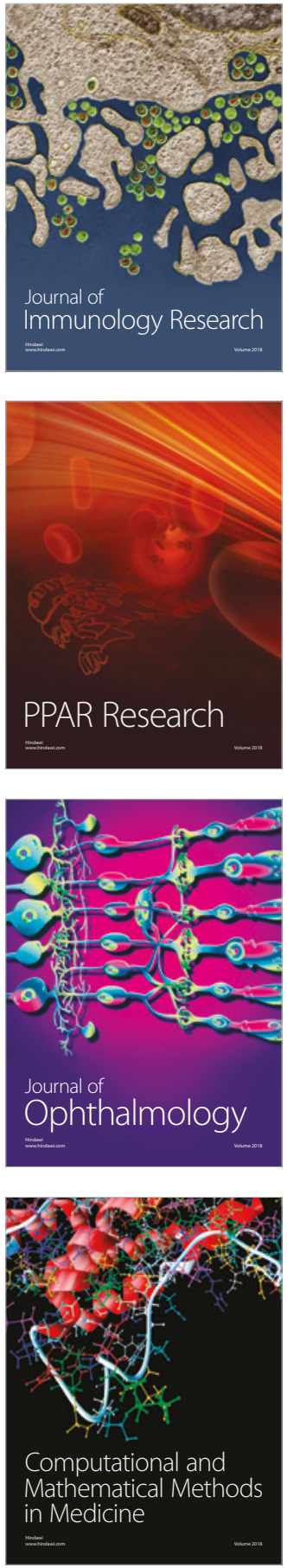

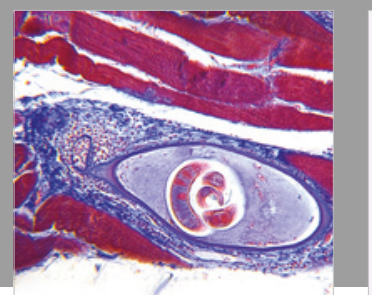

Gastroenterology Research and Practice

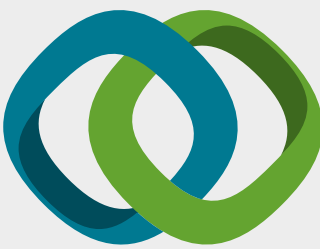

\section{Hindawi}

Submit your manuscripts at

www.hindawi.com
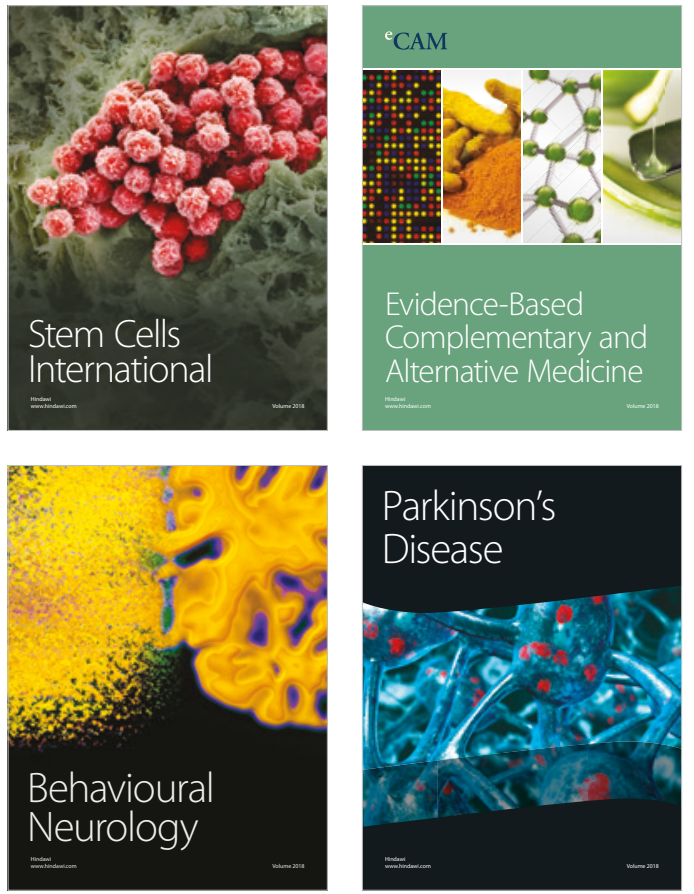

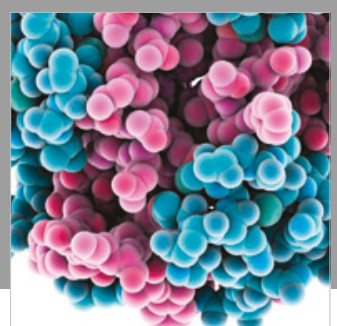

ournal of

Diabetes Research

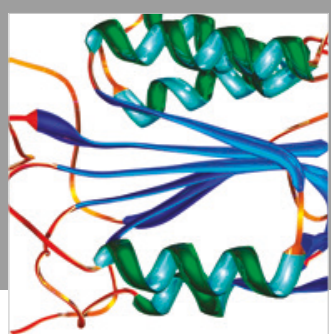

Disease Markers
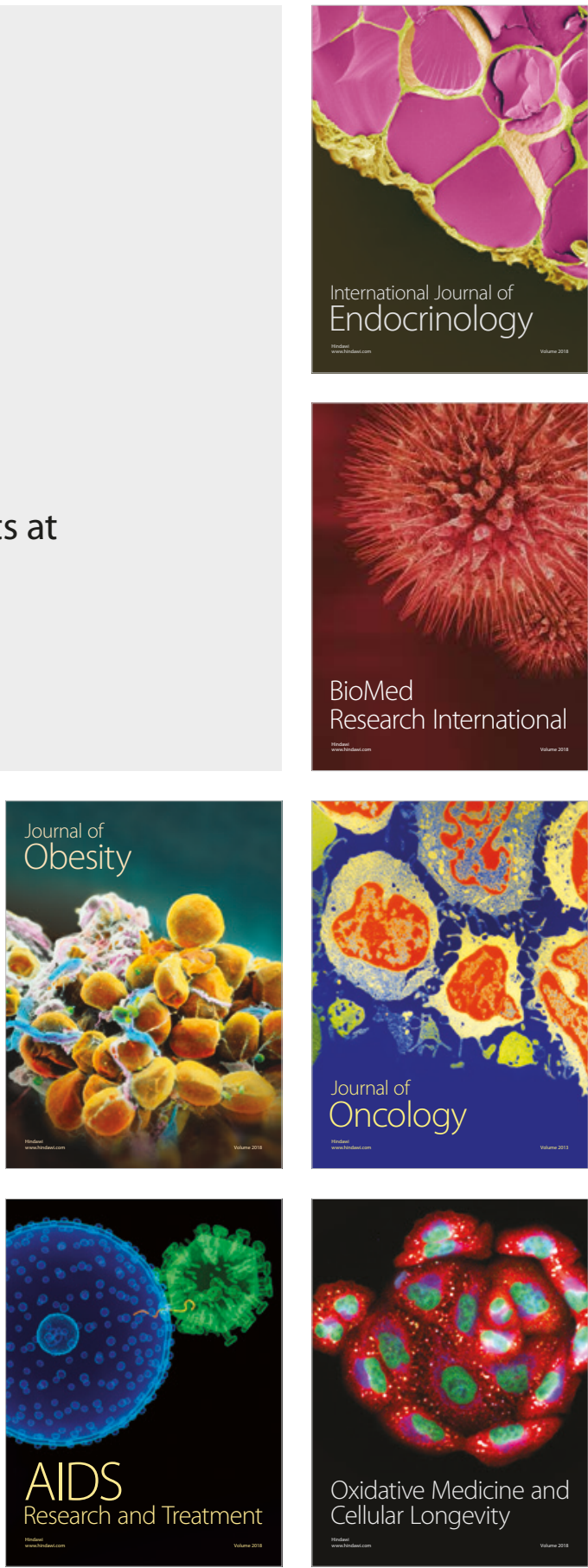